\title{
Preparing the Underprepared: Current Academic Library Practices in Developmental Education
}

\section{Ann Roselle}

This qualitative study examines academic libraries and developmental education. The study was based on semistructured telephone interviews with 31 librarians from 21 states. Interview questions focused on instruction services for developmental students, library collections for developmental students, collaboration with developmental education instructors and learning centers, and professional development related to developmental education. Analysis of the results shows that librarians apply sound pedagogy when infusing basic library skills into developmental education and academic success courses, design assignments with high probability of student success, reduce library anxiety and build student confidence, and develop and promote library collections beneficial to developmental students.

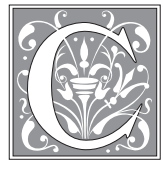

lose to 30 percent of all incoming freshmen are in some way inadequately prepared for college-level work. ${ }^{1}$ This percentage is over 40 percent at public twoyear colleges, ${ }^{2}$ remaining consistent for decades. ${ }^{3}$ Furthermore, 37 states estimate that 79 percent of students entering community colleges will need remediation. ${ }^{4}$ In response, most postsecondary institutions offer some form of developmental education, which may consist of remedial courses in reading, writing, and mathematics, as well as tutoring, mentoring, personal and career counseling, academic advisement, and supplemental instruction to developmental students. ${ }^{5}$

The purpose of this qualitative research study is to examine how academic librar- ies currently participate in developmental education programs. The study identifies patterns in current practices through the examination of these practices. This research fills a knowledge gap reflected by the absence of academic libraries in the developmental education literature and only outdated research and case studies in the library science literature. This research reveals the roles that academic libraries can play in comprehensive developmental education programs and the strategies for integrating into these programs.

\section{Literature Review}

One of the most common characteristics of successful developmental education programs has been a comprehensive system, which has not relied solely on

Ann Roselle is Faculty Librarian at Phoenix College, a Maricopa Community College; e-mail: ann. roselle@pcmail.maricopa.edu. The author would like to thank the librarians who generously gave up their time to participate in this study. 


\section{Current Academic Library Practices in Developmental Education 143}

coursework but has incorporated a variety of services outside the classroom. ${ }^{6}$ Despite the importance of a comprehensive program, references to libraries have been consistently absent from developmental education literature.

Katherine Gerlaugh and her colleagues have studied current practices in community college developmental education programs and have found that services outside the classroom have been important. ${ }^{7}$ While tutoring, academic advising, study skills workshops, orientations, and supplemental instruction have been identified, academic libraries have not been mentioned. The Center for Student Success has studied basic skills education among California community colleges and has developed a guide to effective practices. ${ }^{8}$ While basic skills in reading, writing, mathematics, and studying have been included, basic library skills have been absent from the guide. Robert $\mathrm{H}$. McCabe has identified best practices of developmental education programs, which have linked to all areas of the college. ${ }^{9}$ While many different services have been discussed, academic libraries have garnered only a brief remark that students need to use library databases.

In an earlier report, McCabe explained the importance of information competencies for graduates; yet academic libraries have been absent from the list of what has contributed to a successful program. ${ }^{10}$ Hunter Boylan has identified institutions as exemplars of best practices and has explained that successful developmental education programs are unlikely to have high rates of student success without offering a broad range of support services. ${ }^{11}$ Again, academic libraries have not been mentioned. John E. Roueche, Eileen E. Ely, and Suanne D. Roueche have described the developmental education program at The Community College of Denver (CCD), an exemplary program. ${ }^{12}$ While they have remarked that CCD students need to conduct research, academic libraries have not been mentioned. Roueche and Roueche have recommended that effective developmental education programs have included basic skills in remedial courses; yet library skills have not been mentioned. ${ }^{13}$ Martha Casazza has reviewed the history of developmental education and has explained that the most successful approach has been a comprehensive one. ${ }^{14}$ Once again, academic libraries have been absent. Finally, the NADE Self-Evaluation Guides merely have included "adequate library resources" on an evaluation checklist and have not mentioned academic library services. ${ }^{15}$

The library science literature on academic libraries and developmental education has primarily been represented by case studies, although a few older research articles have been published. Kenneth O. Phifer and Ruth J. Person have surveyed 31 community college libraries and have discovered that libraries have only minimally been involved in developmental education. ${ }^{16}$ Donald T. Rippey and Carol Truett have surveyed 43 Texas community college libraries and have discovered that only a small number of special library services have been provided to developmental students. ${ }^{17}$ Mary Ann Affleck has surveyed 120 community colleges on library instruction and has included questions about instruction adapted for developmental students. ${ }^{18}$ While more specialized instruction has been conducted compared to the Rippey and Truett study, Affleck has still been concerned that almost a third of respondents have failed to adapt library instruction for developmental students.

Several case studies have appeared in the library literature in the 1980s. Coincidentally, the Community and Junior College Libraries Section of the Association of College and Research Libraries has drafted recommendations for library services for underprepared students during this same period. ${ }^{19}$ After a noticeable gap in the 1990s, publications on libraries and developmental education have returned. Case studies have included specialized library instruction in developmental courses,$^{20}$ specialized library projects for 
developmental courses, ${ }^{21}$ a library course paired with a developmental course, ${ }^{22}$ library collaboration with a skills $1 a b,{ }^{23}$ and a library-administered developmental education program. ${ }^{24}$ Other writings have focused on the need for libraries to participate more actively in developmental education..$^{25}$

\section{Methods}

Telephone interviews were conducted with academic librarians throughout the United States. Purposeful sampling ${ }^{26}$ identified academic librarians who had a high likelihood of participating in developmental education programs on their campuses and who could provide insights on the range of library services for developmental students. This sampling was done by selecting librarians from: 1) colleges exemplifying "best practices" by developmental education researchers; ${ }^{27} 2$ ) case studies in the library science literature; 3) postings for good examples of library contributions to developmental education on CJC-L (discussion forum for community college librarians) and LRNASST-L (discussion forum for learning assistance professionals); and 4) participation at a national developmental education conference. Of the 46 librarians contacted to participate, 67 percent (31) accepted.

The study included 31 librarians (25 female, 6 male) interviewed during the months of November and December 2007 and March 2008. The librarians' years of experience at their institutions ranged from 15 months to 35 years. The interviews represented 29 public postsecondary institutions (25 two-year, 4 four-year), from 21 different states, in a variety of settings (city, suburban, and town) with small $(1,000)$ to large $(38,000)$ student populations. When such information was known to them, librarians reported 30 percent to 95 percent of students at their institutions testing at a developmental level in at least one subject area.

During the semistructured interviews, lasting an average of 45 minutes, the re- searcher asked the librarians 20 interview questions on their experiences with the following areas: 1) instruction services for developmental students; 2) library collections for developmental students; 3 ) collaboration with developmental education instructors and learning centers; and 4) professional development in developmental education. Secondary, probing questions were also asked during the course of the interviews. When requested, the researcher provided a copy of the interview questions to the participants prior to the interview sessions.

Each interview was transcribed by the researcher and read multiple times. The researcher used a systematic coding process ${ }^{28}$ to generate concepts from the data. Each interview was first analyzed as a whole entity, using line-by-line coding, where the researcher added coding categories in the transcript margins. Transcript material that was not pertinent to the purpose of the study was coded as extraneous. The researcher also colorcoded recurring concepts. The researcher then used cross-case analysis ${ }^{29}$ to group together answers to common questions, which deepened understanding of the data. During cross-case analysis, the researcher utilized a word processing "find" function to search for recurring words or phrases in the transcripts. Based on the analysis of the concepts generated by the data, the researcher identified patterns in current academic library practices in developmental education.

After the interviews, 14 of the librarians shared documentation with the researcher. The documentation included sample lesson plans, class exercises, course assignments, library handouts, Web site addresses, and internal reports. These documents were checked against the transcripts and validated the interview data. The reliability of the data was also supported by the credibility of the researcher, who was trained to conduct qualitative research by renowned social scientists ${ }^{30}$ and has published results from other qualitative studies. 


\section{Current Academic Library Practices in Developmental Education 145}

\section{Results Instruction}

According to the National Center for Education Statistics, 98 percent of 2-year and 80 percent of 4-year public postsecondary institutions with incoming freshmen offer remedial reading, writing, or mathematics courses. ${ }^{31}$ Therefore, it is not surprising that 90 percent of librarians interviewed provide specialized library instruction to developmental reading and/or writing courses. Librarians integrate instruction into the curriculum as a formal requirement or provide instruction to classes by request of individual instructors. One college offers a complete developmental library course for credit to developmental students.

Fully 83 percent of librarians interviewed indicated that library instruction is incorporated into academic success courses, which are often required for developmental education students. Of these librarians, 60 percent explained that library integration is mandatory in these courses. Integrating the library with academic success courses is particularly appropriate, since research shows a relationship between frequency of library use and the development of effective study skills. ${ }^{32}$ In six cases, the librarian is the formal instructor for the entire academic success course. All of the librarians use evaluation or assessment techniques for the instruction sessions, including satisfaction surveys, class evaluation forms, the one-minute paper, pre and post tests, examination of works citing pages, and feedback from instructors.

Six patterns in current instructional practices with developmental students emerged from the interviews.

(1) Multiple sessions. More than half (52\%) of librarians interviewed teach more than one library session to a developmental class. As a librarian explains:

Instead of coming once for a 50minute class, they come two or three times... for 20 minutes. And then, it is followed up by hands-on [work].
So, they are short bursts of information followed by hands-on.

Another librarian implements multiple sessions for reading courses:

The reading faculty and the librarians designed a progressive group of classes. They end up coming to the library 3 times, instead of just once. The first time... they're doing research on their author. The second time... they're doing what we call "a timeline." The third time... they do web evaluation.... There are three levels of reading and each level comes in several times.... It really does work well.

The librarians indicate many advantages to multiple sessions, including less chance of overwhelming students with information, the ability to teach one thing at a time and focus on a single task, the occasion to review concepts and skills, and the opportunity for students to practice particular skills over and over again. In fact, 19 percent of librarians interviewed emphasized the need for repetition. Another advantage to multiple sessions is that librarians may get to know the students better, which can help in building more engaging relationships with students. A librarian shares:

I've gotten to see the students more than once... and I can see them actually mastering skills. That is a real exciting piece for me. We get a lot of one-on-one time... over and over again.... I can recognize these students, and they all know me.... They see me as the friendly positive face, and they'll actually come and talk to me. Wow! So, that's great.

(2) Simplification. More than 8 out of $10(86 \%)$ librarians interviewed strive to keep lectures, in-class activities, and instructional guides as short and as simple as possible. Librarians guide in-class 
activities with clear expectations and instructions. Librarians keep things simple by teaching one thing at a time, which is especially feasible with multiple sessions, and by focusing on basic library skills, rather than a broad spectrum of information literacy competencies. As a librarian explains with a reading class:

We have focused very much on really basic kinds of things. Using dictionaries, encyclopedias. How those sorts of sources actually work.... We've tied it in the past to definitions, synonyms, and antonyms exercises.

Interestingly, a librarian comments on the relationship between simplified, guided learning and note-taking skills, which are often underdeveloped for developmental education students:

I thought what they really needed was guided learning.... So, I created [fill-in-the-blank] worksheets.... like guided note-taking. They are still learning how to take notes. They're at such a low level.... we want to take as much stress out of it as possible. So, when I am teaching, I'm using the worksheet, and they are using the worksheet.

Simplification often mirrors the experiences students have in their own developmental education courses. A librarian shares:

We wrote up a paragraph defining what we mean by "database"... part of their homework was to know that vocabulary before we came in [to teach].... The instructor had told us that they wouldn't be familiar with this word... so by making that part of their homework, which is typical for them in a reading class, we could really integrate that into the class.

(3) Scaffolding. Scaffolding is a teaching strategy for students who are nov- ice library users. Through scaffolding, librarians limit the complexities of academic libraries and then gradually remove those limits as students gain knowledge and skills in library research. Scaffolding requires extensive instructional support from the librarian and very structured sessions to help students build their understanding of new library concepts and skills. Typically, students work on simplified tasks that make the session more manageable. Librarians vigilantly deliver complete instructions to students, keep students on task, and minimize uncertainty. A librarian describes three sequential highly structured, time-on-task library sessions for a writing course:

The students begin to initiate their research projects by looking up their topic in encyclopedias. The next class... I work with them on how to find a book on their topic. We'll spend maybe 10 to $15 \mathrm{~min}$ utes demonstrating how to do the search... the remainder of the class; students go out into the library, execute a search... and then go to the stacks to find the book. Many times remedial students will need assistance on... finding the book. The following week, the students will come back having narrowed their topic.... I'll demonstrate 10 to 15 minutes on how to do a search for an article... then they'll go out into the library and search on their topic and print an article. Once, we tried to do the book and the article session together. And, it was chaos!

Another librarian reports:

We have implemented this sort of multitiered approach. [The first session] would be very assignmentspecific like biographical references. How do you find out about an author's background? We believe in scaffolding, building upon prior 


\section{Current Academic Library Practices in Developmental Education 147}

knowledge.... I would come back in later on in the semester... we'd have a little review. Remember, how we used these biographical databases? We'll take that same skill you learned, and we're going to apply it to [this other database]. Now, we're going to look for a concept as opposed to a person [for your fivepage research paper].

Through scaffolding, developmental education students are eventually able to apply new library knowledge and skills on their own. A librarian shares:

For the first library session, we are there for the entire time because it is all new, and it is all difficult.... The mechanics of how to download or print or e-mail an article... can take a third of a class. Once they master these basic skills, they can carry them forward to other classes.... What we discovered is that they have mastered [these skills] after the first class.... Now that they have mastered the mechanics, we have been able to actually cut down the second two sessions. We haven't needed as much time.

(4) Hands-on, active learning. More than three-quarters $(77 \%)$ of librarians interviewed identify hands-on and active learning experiences in developmental library sessions as the most effective teaching technique. A librarian explains that active learning in library sessions mirrors student experiences in developmental education courses:

It is never 50 minutes of lecture, because their normal classroom experience isn't set up that way. A lot of active learning strategies that the regular classroom instructors use, we try to bring into the classroom.

Active learning and hands-on components in a library session often involve real "in the stacks" experiences. A librarian explains:

The questions are designed to get them to actually dig into the material.... We hear from the instructors again and again that being out in the library... looking at the resources, has just done a world of good for the students in terms of making them feel comfortable in the library. It is part of helping the students change their experience in college in general.

Hands-on activities also incorporate the use of technology by developmental students, including utilization of ebooks, article databases, online reference sources, and Web sites. For the most part, the librarians indicate that the students are comfortable using technology. Librarians use technology to enhance their own teaching such as embedding videos into lectures or using online games to reinforce concepts. Librarians also load assignments, pathfinders, or other materials onto library Web pages, which is especially helpful to developmental students who lose their copies or miss a class. A librarian describes one use of the Web for students reading a nonfiction book in a developmental English course:

The library developed a webpage... that had vocabulary words and the definitions of those words taken from each chapter... We also found pictures or little videos of places or things that [the author] had mentioned in the book that we put on that website.

Only four of the librarians use online library tutorials with developmental students, achieving marginal success. Those who do experiment with online tutorials caution against using these tutorials as a replacement for face-to-face teaching and learning with developmental students. 
(5) Engagement. More than half (58\%) of librarians interviewed comment on the short attention span of developmental education students and the need to engage students. More than a third (35\%) of librarians use class discussion, whole class or small group, to engage students. Some librarians comment that this technique mirrors teaching methods by developmental education instructors. As a librarian explains:

A very short part is me teaching. For the most part of the class, they are... doing. They are finding their own articles.... There is a lot of discussion during the lab. They'll find a piece of information and they'll ask, "Now, is this appropriate for my timeline?". . . We'll pull together the class for discussion [on this question].... As they read, they have a lot of class discussions... now their discussions are more informed because they have done research.

Librarians also engage students with humor, entertainment and fun exercises. A librarian comments:

Being funny seems to be the best thing even more than what you say about the library.... I did graphical images of a cell phone, a scholarly article, a website... all different [sources of information], and I had the students stand up [representing these sources]. I would ask, "How would you put yourself in order to find the most useful information about a poison ivy rash?" Or, say you need to research whether school uniforms help students get better grades, reorder yourselves.... In one case, the YouTube video actually became most important. And, then they are laughing. They have an awareness of information. And, they know the librarian isn't staid.
To engage students, librarians also use classroom examples and develop assignments that would be of personal interest to students. A librarian shares an experience with an off-putting exercise that does not engage developmental students because it lacks relevance to their lives:

When I first started working with these classes... they would get a handout with some questions to fill out... Find a book... write down the title. That didn't work very well, because they didn't see the purpose behind it. They thought it was boring, busy work, which sort of exacerbated the attitude... that the library was boring. So, I've stopped doing that sort of thing... and make it a lot more practical to their life.

(6) Affective behaviors. More than half (58\%) of librarians interviewed also address noncognitive issues, such as library anxiety and student attitudes toward the library that may affect learning and student success. These librarians consciously address these issues during instruction sessions with developmental students. Research supports this tactic, which shows that library instruction can lower levels of library anxiety. ${ }^{33}$ Some of the librarians try to tackle broader affective behaviors, including overall excitement about learning and student confidence in their overall abilities. A librarian describes her experiences:

It is important for us to help developmental education students feel that the library is a place that is there to help them succeed. I specifically address this with the developmental education students, who often have had a negative experience.... It is amazing. The instructors come back to the classroom, and we hear again and again that coming [for library instruction] has just done a world of good for the students in terms of making them feel comfortable in the library. 


\section{Current Academic Library Practices in Developmental Education 149}

Another librarian shares successes in this area:

[The reading teacher] was very aware of the students' attitudes toward the library. We talked about the fact that just her bringing them in here three times would create a familiarity and lessen the fear... She had them write a half-page letter on what they thought about the library stuff that they did. And the quotes we got... were just mind blowing, like "I used to be afraid of the library, but now I know I can do this!"... You could actually see it in the students as the semester went on.... By the third time... they are so familiar that they are swaggering. Their body language is just really comfortable.

The six patterns (multiple sessions, simplification, scaffolding, hands-on/ active learning, engagement, affective behaviors) in current instructional practices with developmental students interconnect. "Scaffolding" is dependent on "multiple sessions" and "simplification." "Engagement" relies on "hands-on/active learning" experiences. "Multiple sessions" impact the extent to which "affective behaviors" are modified. "Simplification" of library sessions addresses "affective behaviors" by building students' confidence in their abilities. An increase in student confidence may enable students to take on more complex critical thinking tasks. Nearly a third (30\%) of librarians interviewed mention "critical thinking" as an important component of their instruction. Librarians help develop critical thinking skills of developmental students when these students evaluate the usefulness and credibility of a Web site, determine which article is the best fit for an assignment, and incorporate new information from library resources into already existing knowledge.

Many of the patterns in current instructional practices with developmental students also align with good pedagogy for developmental education in general. This includes providing a high degree of structure through scaffold learning, ${ }^{34}$ using class discussions to engage students, ${ }^{35}$ using active learning, ${ }^{36}$ and addressing noncognitive issues that can affect learning. ${ }^{37}$ As the librarians reflect on the different teaching techniques that they use with developmental students, some librarians remark that their experiences influence all of their instruction. A librarian points out:

I think just having worked in depth with these classes has raised our level of consciousness in the library to the point where we've gone back and redeveloped a lot of our general materials to be simpler and more easily understandable. We're all subscribing to the "simpler is better" routine now.

\section{Assignment Design}

Nearly half (45\%) of librarians interviewed express the importance of designing library assignments for developmental courses that have a high probability of student success. In one case, a library assignment is developed for every developmental education course offered at the institution. Developmental education students typically complete assignments during class. This "time-on-task" approach is intended to help ensure student success. In addition, librarians pay careful attention to the design of assignments for student success, including topic selections that can be supported by library collections. A librarian explains:

The reference librarian and I come up with the list of topics... by seeing what we have.... Our whole thrust here is to have them do this developmental project and be confident about doing basic research. So we only want them to use topics that we think they will be successful doing. 
Librarians also stress the importance of designing assignments that utilize easierto-use library resources, especially in terms of readability. A librarian expresses:

We narrow them down to using [a simpler article database] so that they are hopefully finding things on their reading level, and they are not getting frustrated by finding all of those scholarly articles.... For developmental education students... you need to set them up for success. So, by putting them in the right place at the right time, hopefully, their level of frustration will be low.

Another technique from the interviews to ensure student success is to create simplified assignments with step-by-step instructions. Librarians give clear assignment instructions and anticipate problems in advance to eliminate them, which helps reduce student frustration and risk of not completing the assignment. Even specialized in-class handouts are deliberately designed to be simple but complete and often use screenshots to help further explain the directions. A librarian comments:

The instructional design that we put into those handouts, we are pretty careful that everything is right. That we don't leave out steps. That it includes all the information that needs to be there. And lately we have taken to using visual kinds of things, putting in more pictures of what the menus look like rather than just describing them.

Often, course assignments are designed collaboratively with developmental education instructors to ensure student success. A librarian shares:

The librarians tend to be a lot more involved in the creation of the assignments... Maybe in other departments, instructors will say, "Well, if my handout is a little bit out of date, the students will figure it out." The developmental educators know that they have to be really clear with their instructions.... I went out to lunch with one of the instructors because she wanted to show me her assignment. She wanted to talk extensively with me... to make sure that the library had all the resources to support the assignment and that it was within their capabilities.

Assignment design also interconnects with the six patterns in current instructional practices with developmental students. "Multiple sessions" impact how much material is covered in an assignment. "Simplification" impacts the complexity of an assignment. "Engagement" and "hands-on/active learning" impact what students do in an assignment; and when librarians create library assignments with a high probability of student success, they address "affective behaviors." This follows Stephen D. Brookfield's suggestion that creating opportunities for student success, such as fail-proof activities, can build student self-esteem and reduce the level of resistance to learning. ${ }^{38}$

\section{Outreach}

The librarians employ several techniques for integrating the library into developmental education programs, including the following: 1) examining textbooks used in developmental education classes to identify an opening for library instruction; 2) redoing mediocre preexisting assignments to include library skills; 3) reviewing the developmental education curriculum to identify how library classes could fit in; 4) participating on developmental-related committees; 5) capitalizing on strong preexisting relationships with developmental education instructors; and 6) sitting in on developmental education classes to identify opportunities for incorporating the library. A librarian summarizes:

In advance, we get a copy of the syllabus and all of the [developmental 


\section{Current Academic Library Practices in Developmental Education 151}

educators'] assignments. And we get a copy of their textbook.... After looking at their work, we design a draft of how the visit to the library would be structured... and designed to support one of their existing assignments.... When you sit down with the faculty member, you say, "I know that in the fourth week of the semester, you do this, and so we think that a good support mechanism is to have them in the library to do this."

Another librarian reworks a preexisting exercise:

The teacher told me that they are just writing sentences so they can't do research. I asked the instructor if we could work together to come up with some idea. She said, "Well, we are going to be writing an essay about how to do something." And I have [a simple article database], and so we just emphasized that one database.... Even though they were at a very basic level... we did teach them something worthwhile, by just using one resource in the library to help them write an essay.

Another librarian uses a developmental education reading textbook to reach out:

When I looked at their textbook, I did notice that they did something on dictionaries, so I proposed the idea of bringing them in for a session on the dictionary. And we have been doing it every semester since.

A librarian explains a curriculumbased approach:

They had just implemented a new reading requirement... and since [the students] were restricted from taking actual credit courses, a lot of them were taking... classes that they didn't need, where they were just wasting credit time.... They wanted to take a full load to keep their insurance, their Pell grant, whatever. So, some of them were taking three or four PE classes. So I basically created this library course and fought it through curriculum.

Nearly a third (30\%) of the librarians interviewed report that their campus did not have a developmental education committee. For those that did, 59 percent of the librarians reported that a librarian was a member of such a committee. A librarian explains that committee participation helps integrate the library into all developmental education courses:

I go to the developmental education meetings.... And they give me a space at every meeting to talk about the library. Hammering it in. The committee I sit on meets in the library. I suggested that early on, and I make coffee. So, when we meet, we meet in the library, which I did as a sneaky way of ensuring that we stay connected.... Even when they have their Friday night [adjunct] meetings, I open the library and they all come in.

The librarians in this study who proactively contact developmental educators successfully collaborate with them on the design of library instruction sessions and class assignments. No one outreach approach is more effective than another. The outreach practices in this study may inspire academic librarians to integrate basic library skills into developmental education programs.

\section{Learning Assistance and Tutoring}

Learning assistance centers and tutoring services, although typically available to all students, are important components of any comprehensive developmental education program. Interviews provide some evidence that libraries are forming relationships with learning assistance and 
tutoring centers, although many are in the early stages of development. Two librarians describe projects where they help design Web sites. One is for a tutoring center and the other is for a specialized retention department. In addition, two librarians actually work with students in their tutoring centers. A librarian explains:

Each semester we'll designate one librarian to be the contact for the center. And they'll go over twice, maybe three times, a week for an hour and... work with students who are there to receive tutoring. Once in a while, the librarians... are inundated.... But, most of the time, one or two students will approach them in the hour, and it is manageable. The most recent librarian... has made a number of follow-up appointments. So after he has met a student at the center, the student might say, "Hey, can I come see you at your office next week?"

Two librarians teach workshops sponsored by their tutoring centers. Typically, attendance at these workshops is low, except when instructors require attendance or offer attendance as extra credit. A librarian shares:

We have been trying to work together with the learning center for two semesters now... they realized that [library workshops] would be a benefit to the students who are at risk of leaving, of flunking. This semester, we did about three of these and attendance was very low. I told them that we don't get discouraged. We will do this for one student.... So, it's one-on-one. So, they get this great session! Eventually, we'll get the bugs worked out or we'll get a better incentive to pull the students in.

Four of the librarians train their writing tutors on research-related help so that they can serve students better. A librarian describes the training:
We've been doing tutor development for the last six years to train writing tutors [students] to help with basic library research.... And when they get to a place where it is beyond their experience... they bring them in. We teach them basic reference interview skills.... What we're talking about is the whole concept of peer modeling.... You're not an authority figure. You're one of them. You can also share your experiences, where your struggles or difficulties are. And that might also help to build confidence for them.

\section{Library Collections}

Nearly nine out of ten (87\%) librarians interviewed consider reading levels and learning abilities of developmental students when building library collections. This consciousness applies to collection development decisions for circulating books, reference books, and online databases. There are three cases where the easier-to-read materials are identifiable through the online catalogs. Librarians express the importance of their AV collection for developmental students, too, but they are also cautious about attracting students to these collections for fear of discouraging reading.

More than one third (35\%) of librarians interviewed promote certain materials, such as pleasure reading collections, shorter books, books at appropriate reading levels, and mathematics AV materials, to developmental students through reading lists or during library instruction sessions. A librarian explains:

We got a grant to build a collection for anyone who is learning to read in English... things like abbreviated versions of classic novels, English grammar books, visual dictionaries. The writing is in simple language.... [The collection] happens to be right outside of our library instruction classroom. In all of our developmental reading and writing classes, we 


\section{Current Academic Library Practices in Developmental Education 153}

make a point to show the students where that collection is. And we tell them, "If you have to read a book and the book that you were assigned is too complicated, there is probably a book on the same topic that is in this collection."

Despite deliberately selecting materials to support developmental education students, only one library has a written statement about this in their collection development policy. Likewise, even though the librarians participate in their developmental education programs in a variety of ways, only three librarians reported having defined library goals or objectives for these activities. This is unfortunate, because well-defined library goals and objectives for developmental students can strengthen planning efforts and help ensure adequate resource allocation for sustainability. In addition, library strategic and operational documents, such as annual action plans, are typically shared with campus administrators. If library actions for developmental students are included in these documents, campus administrators would be more aware of the ways in which academic libraries contribute to developmental education programs.

\section{Discussion}

The interviews in this study illustrate active ways in which librarians participate in developmental education programs; yet academic libraries are absent from the developmental education literature. This omission can have serious consequences. If campus administrators, developmental educators, regional and national developmental education associations, and policy makers have no knowledge from the literature of how academic libraries support developmental students, it is highly unlikely that academic libraries will ever play a part in any policy or budgetary decision-making related to developmental education at the local, state, or national levels. Developmental education planning decisions will then be made without adequate consultation with academic librarians, who bring unique perspectives from their experiences. Indeed, George Kuh and his colleagues, who have studied colleges that excel at promoting student success, have expressed that "many librarians know a good deal about how students spend their time, what they think and talk about, and how they feel, yet they are underused educational resources." 39

Fortunately, the situation can be remedied if academic librarians increase their communication of current successes, share ideas of future contributions, and more actively participate on developmental-related planning committees. The interviews show that librarians could have a larger representation on campus developmental education committees, which could help ensure that campus decisions are inclusive of library contributions. The interviews also show room for growth in communication and collaboration with learning assistance centers and tutoring services. While it was encouraging to learn that four of the librarians have presented at developmental education conferences, nearly half of the librarians have never attended any developmental education workshop or conference, even at the local level. More vigorous communication of contributions by academic librarians to a broader developmental education audience at regional and national conferences could also help ensure that developmental education researchers and policy makers consider academic libraries when researching and decision making.

The omission of academic libraries may also be due to the lack of published research demonstrating the impact that academic librarians have on student success in terms of retention, persistence, or grades..$^{40}$ Near the end of one interview, a librarian expresses:

I feel in my heart that we really do make a contribution to these students. 
To complement this gut feeling, academic librarians need to gather more evidence on the effects that libraries have on developmental students. This, too, can help remedy the problem of academic libraries being absent in developmental education literature. One librarian interviewed has noticed that the students who completed the developmental library course have a high persistence rate $(90 \%)$ in the following semester. Another librarian has experimented with surveying sections of an English developmental class after participating in a library project and has discovered an improvement in overall attitudes about learning. These measurement methods are headed in the right direction. Research by George Kuh and his colleagues has also begun to highlight how librarians contribute to student engagement and success ${ }^{41}$ which may help to make the case for incorporating libraries into comprehensive developmental education programs.

\section{Conclusion}

While developmental education literature portrays academic library contributions as practically nonexistent, this research shows that libraries actively participate in developmental education programs in a variety of ways. Applying sound pedagogy, librarians teach basic library skills in developmental education and academic success courses so that students have the fundamental knowledge and skills to do college-level work. Through a variety of outreach techniques, librarians integrate the library into developmental education programs and design course assignments with a high probability of student success. Librarians help to reduce library anxiety and build overall self-confidence in learning. In addition, librarians build and promote supportive library collections for developmental students. There are also signs that librarians are working more closely with learning assistance centers and tutoring services to reach out to developmental students in new ways. The need for basic library skills instruction and specialized library services and collections for developmental students is likely to remain for some time. ${ }^{42}$ Academic librarians can use the practices discovered in this study to encourage integration of academic libraries into their own comprehensive developmental education programs.

\section{Notes}

1. National Center for Education Statistics, Remedial Education at Degree Granting Postsecondary Institutions (Washington, D.C.: U.S. Department of Education, Office of Educational Research and Improvement, 2003).

2. Ibid.

3. Hunter R. Boylan and Barbara S. Bonham, "30 Years of Developmental Education: A Retrospective," Journal of Developmental Education 30, no. 3 (2007): 2-4.

4. Davis Jenkins and Katherine Boswell, State Policies on Community College Remedial Education: Findings from a National Survey (Denver, Colo.: Education Commission of the States, Center for Community College Policy, 2002).

5. National Association for Developmental Education, Definition of Developmental Education (National Association for Developmental Education, 2008). Available online at www.nade. net/aboutDevEd/definition.html. [Accessed 19 March 2008]; Martha Casazza, "Developmental Education: Who Are We and Where Did We Come From?" Journal of Developmental Education, 23, no. 1 (1999): 2-6.

6. Patrick D. Saxon and Hunter R. Boylan, “Organizational Structure and Institutional Location of Developmental Education Programs," Research in Developmental Education 21, no. 4 (2007): 1-4; Robert H. McCabe, Yes We Can: A Community College Guide for Developing America's Underprepared (Phoenix, Ariz.: League for Innovation/American Association of Community Colleges, 2003); Hunter R. Boylan, What Works: A Guide to Research-Based Best Practices in Developmental Education (Boone, N.C.: National Center CDE, 2002); Robert H. McCabe, No One to Waste: A Report to Public DecisionMakers and Community College Leaders (Washington, D.C.: Community College Press, 2000).

7. Katherine Gerlaugh, Lizette Thompson, Hunter Boylan, and Hildreth Davis, "National Study of Developmental Education II: Baseline Data for Community Colleges," Research in De- 


\section{Current Academic Library Practices in Developmental Education 155}

velopmental Education 20, no. 4 (2007): 1-4.

8. Center for Student Success, Basic Skills as a Foundation for Student Success in California Community Colleges (Sacramento, Calif.: Center for Student Success, The Research and Planning Group of the California Community Colleges, 2007).

9. McCabe, Yes We Can.

10. McCabe, No One to Waste.

11. Boylan, What Works.

12. John E. Roueche, Eileen E. Ely, and Suanne D. Roueche, In Pursuit of Excellence: The Community College of Denver (Washington, D.C.: Community College Press, 2001).

13. John E. Roueche and Suanne D. Roueche, High Stakes, High Performance: Making Remedial Education Work (Washington, D.C.: Community College Press, 1999).

14. Casazza, "Developmental Education."

15. NADE Self-Evaluation Guides, ed. by Susan Clark-Thayen (Clearwater, Fla.: H \& H Publishing, 1995).

16. Kenneth O. Phifer and Ruth J. Person, "The Role of Community College Libraries and Learning Resource Centers in Literacy Education," Community \& Junior College Libraries 2, no. 1 (1983): 9-22.

17. Donald T. Rippey and Carol Truett, "The Developmental Student and the Community College Library," Community College Review 11, no. 3 (1983): 41-47.

18. Mary Ann Affleck, "Bibliographic Instruction in Community Colleges: Current Practice and the New Standards," Research Strategies 10, no. 1 (1992): 24-33.

19. Community and Junior College Libraries Section, "Library Services to the Academically Disadvantaged in the Public Community College: A Draft," College E Research Libraries News 4 (1987): 189-91.

20. Sandy L. Farrell, "Start-Up of a Mandatory Library Orientation Program in Developmental Education," Community \& Junior College Libraries 13, no. 1 (2004): 51-54; Carmen F. Embry, "A Synergistic Supplement: Remedial Writing Instructors and Reference Librarians Teamed to Build Confidence in the Underprepared Student at the University of Louisville," in The Librarian in the University, eds. H. Palmer Hall and Caroline Byrd (Metuchen, N.J.: Scarecrow Press, 1990), 166-70; Tisa Houck, "Library Skills Instruction for Developmental Courses," Community \& Junior College Libraries 5, no. 2 (1988): 53-56; Mary A. Ramey. "Learning to Think about Libraries: Focusing on Attitudinal Change for Remedial Studies Students," Research Strategies 3, no. 3 (1985): 125-30.

21. Mark De Jong and Sandra Eckard, "Faculty and Librarian Cooperation in Designing Course Projects for At-Risk Freshmen," NADE Digest 1, no. 2 (2005): 8-13; Celia C. Suarez, "The Library and Remedial/Developmental/Compensatory Education: A Case Study," Library Trends 33, no. 4 (1985): 487-99.

22. Virginia P. Sorensen, "Bibliographic Instruction in a Developmental Studies Program: A Paired Course Approach," Research Strategies 6, no. 4 (1988): 161-67.

23. Adele Schneider and Morton L. Fuhr, "The Library's Role in Remediation: A Cooperative Program of Physical and Philosophical Integration at Kingsborough Community College," Community $\mathcal{E}$ Junior College Libraries 1, no. 2 (1982): 47-58.

24. Stephen L. Gerhardt, "Library Administered Remediation: One Program That Works," Community \& Junior College Libraries 4, no. 2 (1986): 41-44.

25. Susan E. Thomas, "The Necessary Library Revolution in Community College Developmental and Remedial Programs," Community and Junior College Libraries 9, no. 2 (2000): 47-57; Margaret Holleman, Julie Beth Todaro-Cagle, and Barbara Murray, "Role of the LRC in Developmental and Literacy Education," New Directions for Community Colleges 18, no. 3 (1990): 23-30.

26. Michael Quinn Patton, Qualitative Research and Evaluation Methods, 3rd ed. (Newbury Park, Calif: Sage Publications, 2002).

27. McCabe, Yes We Can; Boylan, What Works; Roueche, Ely, and Roueche, In Pursuit of Excellence.

28. Amanda Coffey and Paul Atkinson, Making Sense of Qualitative Data (Thousand Oaks, Calif.: Sage Publications, 1996).

29. Matthew B. Miles and A. Michael Huberman, Qualitative Data Analysis, 2nd ed. (Thousand Oaks, Calif.: Sage Publications, 1994).

30. The researcher and author of this article studied under Dr. Howard S. Becker and Dr. Charles C. Ragin when obtaining a Master's in Sociology from Northwestern University.

31. National Center for Education Statistics, Remedial Education at Degree Granting Postsecondary Institutions.

32. Leticia Osequera, "How First-Year College Students Use Their Time," in The Role of the Library in the First College Year, ed. Larry Hardesty (Columbia, S.C.: University of South Carolina, 2007), 29-47.

33. Alison Cleveland, "Library Anxiety: A Decade of Empirical Research," Library Review 
53, no. 3/4 (2004): 177-85; Anthony J. Onwuegbuzie, Qun G. Jiao, and Sharon L. Bostick, Library Anxiety: Theory, Research, and Applications (Lanham, Md.: Scarecrow Press, 2004); Anna M. Van Scoyoc, "Reducing Library Anxiety in First-Year Students," Reference E User Services Quarterly 42, no. 4 (2003): 329-41.

34. Center for Student Success, Basic Skills as a Foundation for Student Success in California Community Colleges.

35. Stephen D. Brookfield, The Skillful Teacher: On Technique, Trust, and Responsiveness in the Classroom, 2nd ed. (San Francisco, Calif.: Jossey-Bass, 2006); see note 9 above.

36. Center for Student Success, Basic Skills as a Foundation for Student Success in California Community Colleges; Boylan, What Works.

37. Center for Student Success, Basic Skills as a Foundation for Student Success in California Community Colleges; Tracy L. Skipper, Student Development in the First College Year: A Primer for College Educators (Columbia, S.C.: University of South Carolina, 2005); Patricia Smittle. "Principles for Effective Teaching in Developmental Education," Journal of Developmental Education 26, no. 3 (2003): 10-16.

38. Brookfield, The Skillful Teacher.

39. George Kuh, Jillian Kinzie, John H. Schuh, Elizabeth J. Whitt, and Associates, Student Success in College: Creating Conditions that Matter (San Francisco: Jossey-Bass, 2005): 312.

40. College Students Surveys Project Group, Library Use, Information Literacy and Student Success: Research Review [working bibliography] (ACRL Institute for Information Literacy, 2008). Available upon request from author.

41. George D. Kuh, Polly D. Boruff-Jones, and Amy E. Clark, "Engaging Students in the First College Year: Why Academic Librarians Matter," in The Role of the Library in the First College Year, ed. Larry Hardesty, 17-28 (Columbia, S.C.: University of South Carolina, 2007); Kuh, Kinzie, Schuh, Whitt, and Associates, Student Success in College; George D. Kuh and Robert M. Gonyea. "The Role of the Academic Library in Promoting Student Engagement in Learning," College $\mathcal{E}$ Research Libraries 64, no. 4 (2003): 256-82.

42. National Center for Education Statistics, Remedial Education at Degree Granting Postsecondary Institutions; Boylan and Barbara S. Bonham, "30 Years of Developmental Education"; Jenkins and Boswell, State Policies on Community College Remedial Education.

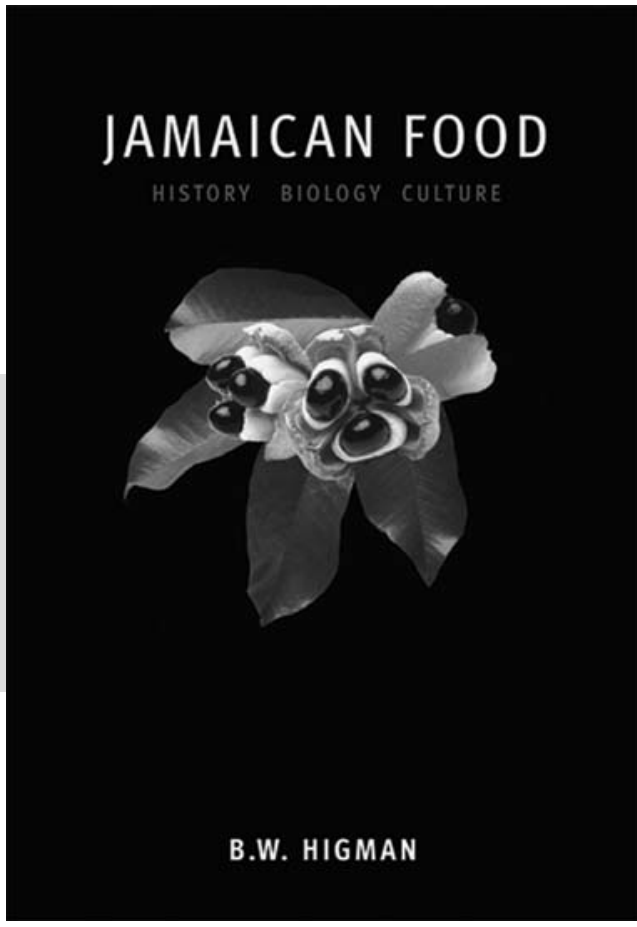

ISBN 978-976-640-205-I • 600pp • 7 × 10 Maps, illustrations and four-color plates US\$70 (s) Cloth

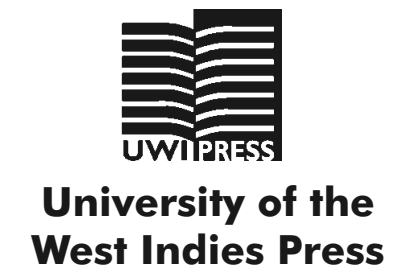

JAMAICA • BARBADOS • TRINIDAD \& TOBAGO • OPEN CAMPUS

Finalist/Honorable Mention Archeology \& Anthropology PROSE Awards Association of American Publishers

Checks and requests to:

Customer Service

Longleaf Services, Inc.

P.O. Box 8895

Chapel Hill, NC 27515-8895

Tel: (800) 848-6224; Fax: (800) 272-6817

Email: customerservice@longleafservices.org 